\title{
Evaluation Model Analysis and Application of Students' Learning Ability Based on Fuzzy Evaluation Method and Hierarchical Theory
}

\author{
Wenliu Zhang \\ Jiangxi University of Traditional Chinese Medicine \\ Nanchang, China \\ zh_angwenliu@126.com
}

Keywords: comprehensive evaluation; AHP; influence factor; fuzzy mathematics; matrix equation; weight coefficient

\begin{abstract}
The twenty-first century is the age of knowledge economy, and innovation ability is the mark of a country comprehensive national power. Creative education as an important part of quality education is more and more concerned by the whole society. Through the comparison of creative education and traditional education, it can point out that the creative education is superior to the traditional education, the use of mathematical model evaluation method carries out comprehensive evaluation on the creative education university students, and the effect of learning ability rate is studied, finally it can point out the creative education on university students innovation ability and improving the ability of learning have a great help.
\end{abstract}

\section{Introduction}

Quality education begins to get the attention and favor of the whole society, and creative education becomes the main trend of modern education. In the present situation, problems and countermeasures of China college creativity education, Qi Fang points that learning creation has become the most important aim of current education, which is the main trend of the international education, through the ideal model and the reality as comparison, to analyze the China higher education creative education present situation and the existence question, on this basis, the combination of the ideal mode of creative education puts forward to strengthen some suggestions of our college creativity education [1]; In the text of thinking about college creativity education, Chen Guohua points out that the creative education is higher education 's important tasks and goals, the training of creative talents rely on school creative education, and school education way is teaching [2,3]; In the construction of creative university education mode, Wei Ming and $\mathrm{Hu}$ Qitao point out that the creative education should reflect each link of university education, including students self learning, classroom discussion under the guidance of teachers, scientific research based on self-study and discussed; the construction of creative university education mode must change traditional education concept, change the teachers role, curriculum setting and contents, teaching materials and so on. In the colleges, the promotion of creative education is the only route of cultivating innovative talents one [4]; In the construction of creative university education mode, Wei Ming and Hu Qitao point out that the creative education should reflect each link of university education, including students self-learning, classroom discussion under the guidance of teachers, scientific research based on self-study and discussed; the construction of creative university education mode must change traditional education concept, change the teachers role, curriculum setting and contents, teaching materials and so on. In the colleges, the promotion of creative education is the only route of cultivating innovative talents $[5,6]$.

\section{Creative Education Concept}

China traditional education way is the "spoon-feeding" teaching, teachers are immutable and frozen teaching, and students apply mechanically learning, this kind of education not only imprison the students thought, but also erase the personality of students. With the continuous development of innovative society, the traditional education way has been completely unable to adapt to the needs of the times, in this context, creative education has been put on the agenda. Creative education teaching 
goal is to inspire students' creative spirit, to arouse students' learning enthusiasm and initiative, so as to cultivate new scientific and technological talents [7].

A. Application Status of Creative Education in Colleges

The quality level of higher education is the flag of a country comprehensive national strength, the traditional higher education has been unable to meet the demands of modern society, it must carry out education reforms, and creative education is the best choice at present [8]. In 1930s, the creative education has been launched as a pilot, it has been more mature. Creative education in China started relatively late, and it has been popularized in college, however the effect is not very obvious. The different regions of the university are investigated as shown in Table 1.

\begin{tabular}{|c|c|c|c|c|c|}
\hline Region & $\begin{array}{c}\text { School } \\
\text { name }\end{array}$ & $\begin{array}{c}\text { Creative } \\
\text { education } \\
\text { teaching } \\
\text { school } \\
\text { hour } \\
\end{array}$ & $\begin{array}{c}\text { Traditional } \\
\text { education } \\
\text { teaching } \\
\text { school } \\
\text { hour } \\
\end{array}$ & $\begin{array}{l}\text { Total } \\
\text { school } \\
\text { hours }\end{array}$ & $\begin{array}{c}\text { The } \\
\text { promotion } \\
\text { rate of } \\
\text { creative } \\
\text { education }\end{array}$ \\
\hline \multirow{3}{*}{$\begin{array}{l}\text { East } \\
\text { coast }\end{array}$} & $\begin{array}{l}\text { Shanghai } \\
\text { Jiao Tong } \\
\text { University }\end{array}$ & 95 & 5 & 100 & $95 \%$ \\
\hline & $\begin{array}{l}\text { Fudan } \\
\text { University }\end{array}$ & 96 & 4 & 100 & $96 \%$ \\
\hline & $\begin{array}{l}\text { Nanjing } \\
\text { University }\end{array}$ & 92 & 8 & 100 & $92 \%$ \\
\hline \multirow{3}{*}{$\begin{array}{l}\text { Central } \\
\text { region }\end{array}$} & $\begin{array}{l}\text { Nanchang } \\
\text { University }\end{array}$ & 98 & 2 & 100 & $98 \%$ \\
\hline & $\begin{array}{l}\text { Zhengzhou } \\
\text { University }\end{array}$ & 95 & 5 & 100 & $95 \%$ \\
\hline & $\begin{array}{l}\text { Wuhan } \\
\text { University }\end{array}$ & 93 & 7 & 100 & $93 \%$ \\
\hline \multirow{3}{*}{$\begin{array}{l}\text { West } \\
\text { area }\end{array}$} & $\begin{array}{l}\text { Yunnan } \\
\text { University }\end{array}$ & 90 & 10 & 100 & $90 \%$ \\
\hline & $\begin{array}{l}\text { Southwest } \\
\text { Forestry } \\
\text { University }\end{array}$ & 85 & 15 & 100 & $85 \%$ \\
\hline & $\begin{array}{l}\text { Chongqing } \\
\text { Medical } \\
\text { University }\end{array}$ & 86 & 14 & 100 & $86 \%$ \\
\hline
\end{tabular}

From the Table1, it can be seen that the creative education has been widely used in the teaching of Chinese higher education, however due to different regional economic development institutions, institutions faculty different and other reasons, resulting in the eastern coastal region and the central region of the creative education are widely applied, and the western region of the creative education promotion rate is relatively low.

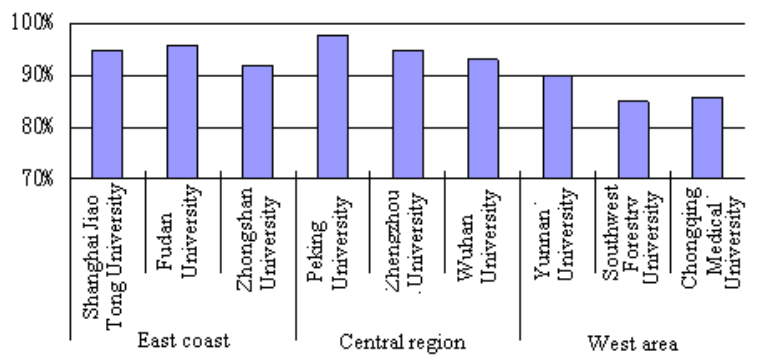

Figure 1. The promotion rate of creative education statistical graph in college

\section{B. The Pros and Cons Comparison of Creative Education and Traditional Education}

Creative education as an important part of quality education, compared with traditional education mode, its education idea and education goal have the very big difference, through the investigation, its statistics are given in Table 2.

TABLE II. COMPARISON TABLE OF CREATIVE EDUCATION AND TRADITIONAL EDUC
\begin{tabular}{|l|l|l|}
\hline \multicolumn{1}{|c|}{ Creative education } & Traditional education \\
\hline Education goal & $\begin{array}{l}\text { Focus on the use of } \\
\text { knowledge }\end{array}$ & $\begin{array}{l}\text { Emphatically grasp } \\
\text { knowledge }\end{array}$ \\
\hline Education method & $\begin{array}{l}\text { Focus on inspiration, } \\
\text { student active learning }\end{array}$ & $\begin{array}{l}\text { Focus on teaching, } \\
\text { student passive learning }\end{array}$ \\
\hline $\begin{array}{l}\text { Education } \\
\text { characteristics }\end{array}$ & $\begin{array}{l}\text { Focus on the cultivation } \\
\text { of students creative spirit }\end{array}$ & $\begin{array}{l}\text { Focus on learning } \\
\text { textbook knowledge }\end{array}$ \\
\hline Classroom form & Flexible, vivid image & $\begin{array}{l}\text { The traditional single, } \\
\text { lack of vitality }\end{array}$ \\
\hline
\end{tabular}




\section{College Students Creative Education Evaluation Based on Fuzzy Evaluation Method}

Creative education is mixed in the process of popularization and application of university, on the one hand, creative education emphasizes the students' autonomous learning, however some students self-discipline is poor, it is infinite freedom, to indulge themselves; on the other hand, creative education encourages students to show their personality, because some students take the wrong as personality, leading to development abnormalities of some students thought. This paper uses fuzzy evaluation method to carry out evaluation on university students' creative education [9].

Effects of creative education have many kinds of factors in the application of university, and this paper adopts a hierarchical evaluation method. First, the impacts of various factors carry out hierarchy planning as shown in Table 3.

\begin{tabular}{|c|c|c|}
\hline $\begin{array}{c}\text { First layer } \\
\text { influencing } \\
\text { factors }\end{array}$ & $\begin{array}{c}\text { Second layers } \\
\text { influencing factors }\end{array}$ & $\begin{array}{c}\text { Third layers } \\
\text { influencing factors }\end{array}$ \\
\hline \multirow[b]{2}{*}{$\begin{array}{l}\text { Teaching } \\
\text { environment } \\
u_{1}(0.4)\end{array}$} & $\begin{array}{l}\text { Teaching conditions } \\
u_{11}(0.25)\end{array}$ & \multirow[b]{2}{*}{$\begin{array}{l}\text { Hardware } \\
\text { facilities } u_{111}(0.4) \\
\text { Software } \\
\text { infrastructure } \\
u_{112}(0.6)\end{array}$} \\
\hline & $\begin{array}{l}\text { Teachers strength } \\
u_{12}(0.35) \\
\text { Course arrangement } \\
u_{13}(0.25) \\
\text { The number of } \\
\text { students } u_{14}(0.15)\end{array}$ & \\
\hline $\begin{array}{l}\text { Students own } \\
\text { conditions } \\
u_{2}(0.3)\end{array}$ & $\begin{array}{lr}\text { Learning } & \text { interest } \\
u_{21}(0.40) & \\
\text { Learning } & \text { objective } \\
u_{22}(0.30) & \\
\text { Learning } & \text { motivation } \\
u_{23}(0.30) & \end{array}$ & \\
\hline $\begin{array}{l}\text { Teachers } \\
\text { personal } \\
\text { condition } \\
u_{3}(0.3)\end{array}$ & $\begin{array}{ll}\text { Personal } & \text { ability } \\
u_{31}(0.4) & \\
\text { Personal } & \text { teaching } \\
\text { habits } u_{32}(0.3) & \\
\text { Personal } & \text { concept } \\
u_{33}(0.3) & \end{array}$ & \\
\hline
\end{tabular}

In the application of college students creative education, assumption the evaluation result set is $\mathrm{V}=\{\mathrm{A}, \mathrm{B}, \mathrm{C}, \mathrm{D}\}$ that respectively represent the four evaluation results, and arranging survey data can get the fuzzy evaluation form as shown in Table 4.

\begin{tabular}{|l|c|c|c|c|}
\hline \multicolumn{1}{|c|}{ TABLE IV. THE VARIOUS FACTOR FUZZY EVALUATION FORM } \\
\hline Teaching environment & A & B & C & D \\
\hline Teaching conditions & 0.91 & 0.87 & 0.85 & 0.83 \\
\hline Teachers strength & 0.92 & 0.88 & 0.90 & 0.84 \\
\hline Course arrangement & 0.88 & 0.91 & 0.87 & 0.85 \\
\hline The number of students & 0.65 & 0.60 & 0.53 & 0.66 \\
\hline Students own conditions & 0.54 & 0.52 & 0.60 & 0.53 \\
\hline Learning interest & 0.76 & 0.72 & 0.80 & 0.82 \\
\hline Learning objective & 0.90 & 0.87 & 0.91 & 0.76 \\
\hline Learning motivation & 0.67 & 0.71 & 0.78 & 0.69 \\
\hline Teachers personal condition & 0.72 & 0.76 & 0.75 & 0.81 \\
\hline Teachers personal ability & 0.80 & 0.75 & 0.82 & 0.74 \\
\hline Teachers teaching habits & 0.81 & 0.84 & 0.76 & 0.84 \\
\hline Hardware facilities & 0.61 & 0.66 & 0.53 & 0.51 \\
\hline Software infrastructure & 0.62 & 0.67 & 0.71 & 0.59 \\
\hline be shown that influence & 0.82 & 0.76 & 0.85 & 0.79 \\
\hline
\end{tabular}

From the table 3, it can be shown that influence creative education is divided into three layers in the factors of university application: 
The first layer influencing factor set is $U=\left\{u_{1}, u_{2}, u_{3}\right\}$; second layer influencing factor set is $u_{1}=\left\{u_{11}, u_{12}, u_{13}, u_{14}\right\}, u_{2}=\left\{u_{21}, u_{22}, u_{23}\right\}$ and $u_{3}=\left\{u_{31}, u_{32}, u_{33}\right\}$; third layer influencing factor set is $u_{11}=\left\{u_{11}, u_{112}\right\}$.

Hierarchical fuzzy evaluation is $u_{11}=\left\{u_{111}, u_{112}\right\}$; Weight coefficient $A_{11}=\{0.5,0.5\}$ can get the third layers of impact factors fuzzy evaluation matrix $R_{11}=\left(\begin{array}{llll}0.62 & 0.67 & 0.71 & 0.59 \\ 0.82 & 0.76 & 0.85 & 0.79\end{array}\right)$.

Through the mathematical model, it can get $B_{11}=A_{11} \cdot R_{11}=(0.41,0.53,0.76,0.64)$; similarly, it can be obtained

$$
B_{1}=A_{1} \cdot R_{1}=\left(\begin{array}{llll}
0.25 & 0.35 & 0.25 & 0.15
\end{array}\right)\left(\begin{array}{rlll}
0.91 & 0.87 & 0.85 & 0.83 \\
0.92 & 0.88 & 0.90 & 0.84 \\
0.88 & 0.91 & 0.85 & 0.87
\end{array}\right)=(0.87,0.83,0.76,0.89)
$$

The above results indicate that due to the effect on various objective and subjective factors, making the creative education implementation produces such effects, and however on the whole, major colleges' students are positive on creative education evaluation, reflecting the university students on the desire and welcome of creative education.

In Table 2, it can be seen that the teaching objectives of creative education emphasize students on the use of knowledge, and traditional education only emphasizes that students master the knowledge of teacher teaching; the teaching method of creative education is to pay attention to inspire students' curiosity for knowledge, the ability of cultivate students active learning, and the traditional education is only pay attention to teaching knowledge, students only can passive learning; the teaching characteristics of creative education emphasizes the cultivation of students creative spirit, and the traditional education pays more attention to the textbook knowledge, obliterating the creativity of students; the form of creativity education classroom is flexible with theatrical performances, knowledge competitions, group discussions and other forms, and traditional education is dull the "spoon-feeding" teaching that is lack of vitality [10].

\section{Effect Analysis of Creative Education on College Students Learning Ability}

With the continuous development of global integration, competition between the worlds is increasingly fierce, and the competition of comprehensive national strength is the competition of science and technology. The development of science and technology relies on education to support, the traditional education method is difficult to meet the modern society for the demand of high quality innovative talents, education reform is imperative.

Creative education is to cultivate college students' autonomous learning ability and innovative consciousness, stimulating the creation desire of university students, to train qualified construction professionals for building an innovative society. The creative education on college students' learning ability can produce what kind of effect, and this paper uses a mathematical model to carry on scientific analysis.

Assuming that creative education affects college students' learning ability factor set $U=\left\{u_{1}, u_{2}, \cdots, u_{n}\right\}$, according to the different of influence degree, it is divided into sub-factors ${ }^{\text {set }} U_{1}, U_{2}, \ldots U_{s}$, in which $U_{i}=\left\{U_{i 1}, U_{i 2}, \ldots U_{i n}\right\}, i=1,2, \ldots s$, and meeting: (1) $n_{1}+n_{2}+\cdots+n_{s}=n$; $U_{1} \cup U_{2} \cdots \cup U_{s}=U ;(3)$ any $i \neq j, U_{i} \cap U_{j}=\theta$.

For each impact factors, they are separately evaluated analysis, assuming that $V=\left\{v_{1}, v_{2}, \cdots, v_{m}\right\}$ is assessment result set, factor and $U_{i}$ with respect to the weight coefficient of $\mathrm{V}$ are $A_{i}=\left\{a_{i 1}, a_{i 2}, \cdots, a_{i n}\right\}$. Through the evaluation matrix $R_{i}$, it can get the evaluation vector $B_{i}=R_{i} \cdot A_{i}=\left(b_{i 1}, b_{i 2}, \cdots, b_{i m}\right) \quad i=1,2, \cdots, s$.

$U_{i}$ is considered as a single factor, for the second layer of factor set $K=\left\{u_{1}, u_{2}, \cdots, u_{s}\right\}$, it can get the appraisal matrix of $\mathrm{k}$ that is:

$$
R=\left[\begin{array}{c}
B_{1} \\
\boldsymbol{B}_{2} \\
\vdots \\
\boldsymbol{B}_{s}
\end{array}\right]=\left[\begin{array}{cccc}
b_{11} & b_{12} & \cdots & b_{1 m} \\
b_{21} & b_{22} & \cdots & b_{2 m} \\
\vdots & \vdots & \ddots & \vdots \\
b_{s 1} & b_{s 2} & \cdots & b_{s m}
\end{array}\right]
$$


For each $U_{i}$ as a part of $U$, it reflects the factors $U$ on college students' the affect degree of learning ability, and then according to the size of the extent of their impact, to give their weight coefficient distribution, $A=\left(a_{1}, a_{2}, \cdots, a_{s}\right)$ can get the evaluation vector $B=A \cdot R=\left(b_{1}, b_{2}, \cdots, b_{m}\right)$.

According to gray fuzzy evaluation system theory, to respectively calculate correlation coefficient $\xi_{i}(k)$ of different levels factor set, namely

$$
\xi_{i}(k)=\frac{\min _{i} \min _{k}\left|C_{k}^{\theta}-C_{k}^{i}\right|+\rho_{i} \max _{k}\left|C_{k}^{\theta}-C_{k}^{i}\right|}{\left|C_{k}^{\theta}-C_{k}^{i}\right|+\rho \max _{i} \max _{k}\left|C_{k}^{\theta}-C_{k}^{i}\right|} \quad \rho \in[0,1]
$$

$\xi_{i}(k)$ can get the evaluation matrix

$$
E=\left|\begin{array}{cccc}
\boldsymbol{\xi}_{1}(1) & \boldsymbol{\xi}_{1}(2) & \cdots & \boldsymbol{\xi}_{1}(n) \\
\boldsymbol{\xi}_{2}(1) & \boldsymbol{\xi}_{2}(2) & \cdots & \boldsymbol{\xi}_{2}(n) \\
\vdots & \vdots & \ddots & \vdots \\
\boldsymbol{\xi}_{m}(1) & \boldsymbol{\xi}_{m}(2) & \cdots & \boldsymbol{\xi}_{m}(n)
\end{array}\right|
$$

Through the above all kinds of formulas, to get the creative education on the university students' learning ability effect result that is $R=E \times W$, namely

$$
r_{i}=\sum_{k=1}^{n} W(k) \times \xi_{i}(k)
$$

The investigation of the data substitutes into the above formula, it can get the following conclusions: the learning ability of some poor self-discipline university students is improved the role of small for the creative education, sometimes having some side effects; however, for the majority of learning positive college students, creative education can lead them active asking question and learning, to play a very important role in their autonomous learning ability improvement that is the goal of the university education. Therefore, the creative education is a positive and active impact on the learning ability of college students.

\section{Conclusion}

Creative education is an exploration of the education reform under the new situation of building an innovative society education, compared with the traditional education mode, creative education can stimulate student's innovative desire, developing students' innovative consciousness and practical ability, contributing to the development of students' personality and super long play. Under the new situation of the increasingly fierce international competition, we should continue to promote creative education, developing the intellectual talents with innovative spirit and innovative ability in the nationwide, to constantly enhance China comprehensive competitiveness.

\section{References}

[1] Qi Fang. China college creativity education present situation, problems and countermeasures. Journal of Tianjin University, 2009(3): 112-114.

[2] Chen Guohua. Thought of college creativity education. Journal of Henan business college, 2009(11):89-92.

[3] Nan Guixing, Sun Shidong, Chen Qiaoli e.i. Discussion on creative education. Nursing practice and research, 2009 (01): 245-247.

[4] Wei Fajun. Modernization education calling for creative education. Journal of Luohe Vocational Technology College, 2009(02): 167-169.

[5] Wei Ming, Hu Qitao. Construction creative of the university education mode. Journal of Anhui Agriculture University, 2010(6): 112-114.

[6] Liu Yongxiu. High school creative education. Heilongjiang higher education research, 2009(10): 67-69.

[7] Li Haipeng. Reforming and practice of our innovative personnel training mode. Journal of Xi'an Jiao Tong University (SOCIAL SCIENCE EDITION), 2011(03): 180-182.

[8] Xue Fengde. Study of creative education theory in Japan. Foreign education research, 2009 (03): 145-147.

[9] Liu Daoyu. Construction of the university creative education mode. Education development research, 2010 (12): 212-214.

[10] Knospe H eiko, Pohl H artmut. RFID Security. Information security technical report, 2009(4): 102-104. 